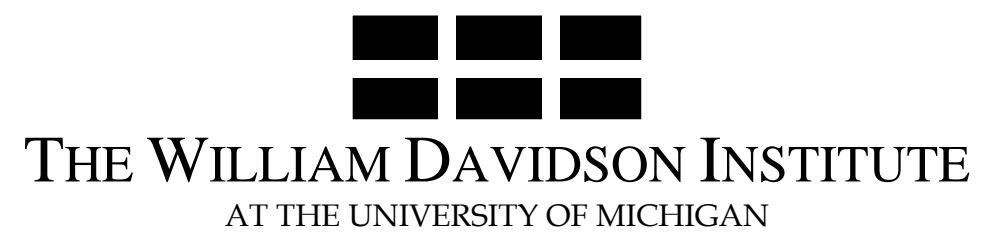

AT THE UNIVERSITY OF MICHIGAN

\title{
Money Market Integration and Sovereign CDS Spreads Dynamics in the New EU States
}

By: Peter Chobanov, Amine Lahiani \& Nikolay Nenovsky

William Davidson Institute Working Paper Number 1002 October 2010 


\title{
Money Market Integration and Sovereign CDS Spreads Dynamics in the New EU States ${ }^{1}$
}

\author{
Petar Chobanov \\ University of National and World Economy, Sofia \\ pchoby@gmail.com \\ Amine Lahiani \\ University of Orléans, LEO \\ amine.lahiani@univ-orleans.fr \\ Nikolay Nenovsky \\ University of National and World Economy, Sofia \\ University of Orléans, STUDIUM \\ nenovsky@gmail.com
}

\begin{abstract}
Summary: When the first phase of the crisis focused primarily on the interbank market volatility, the second phase spread on the instability of public finance. Although the overall stance of public finances of the new members is better than the old member countries, the differences within the new group are significant (from the performer Estonia to the laggard Hungary). Sovereign CDS spreads have become major variables focused on risks and expectations about the fiscal situation of different countries. In the paper we investigate, first, whether there is a link in the new member states (NMS) between the expectations about the condition of their public finances and the dynamics of money markets, including integration of national money markets with the euro area. In others word we contribute to clarify the relationship between fiscal and liquidity risks as major components of systemic risk. Second, we look on the particularities of this relationship through the different phases of the crisis and across the different countries using different monetary regimes. This concerns mostly two opposite extreme monetary regimes, namely, currency boards (and quasi-fixed exchange rate) - Bulgaria, Estonia, Latvia, Lithuania, or inflation targeting - Poland, Czech Republic, Hungary and Romania. The results obtained form the high frequency panel data models support the theoretical hypotheses and policy intuition that exists strong relationship between the liquidity risk (measured by the short term money markets) and fiscal risk (measured by CDS) and that this link is extremely unstable and in some sense nonlinear during the financial crisis. Our study confirm that the strong link between monetary and public finance risk as apart of total systemic risk increase during the crisis especially for currency boards regimes, when the link becomes stronger and pronounced. For the inflation targeting countries the link became weaker and less pronounced.
\end{abstract}

JEL code: E43; G10; P20; F31; F34

Key words: money markets, sovereign CDS spreads, EU enlargement, monetary regimes, financial crisis

\footnotetext{
${ }^{1}$ The paper was presented at the VII- èmes Journées d'économie financière, El Mouradi Gammarth, Tunis 14 et 15 octobre 2010.
} 


\section{Introduction}

The crisis placed again in the center of attention on the EU stability and expansion of the euro area, on monetary and fiscal integration of new countries and their resistance to various types of shocks.

In the few years before the onset of the crisis, the EU enlargement moved without significant disruptions and according to the institutional frameworks needed for the next step - the enlargement of the euro zone. The main theoretical discussion was limited generally to the question of how different types of monetary and exchange rates regimes are able to fulfill criteria for nominal and real convergence and to protect against asymmetric shocks. As a rule, the monetary policies of the NMS closely followed the ECB policy, either in the discretionary regime (inflation targeting), or passively (currency boards or quasi fixed exchange rate). The convergence of monetary variables, particularly interest rates was relatively well developed, and generally satisfactory nominal integration was observed. This concerned especially the interbank money market, which is not only a key element in the transmission of monetary policy, but also serves as an indicator for the liquidity stance, for interbank risk and for overall confidence in the banking system.

Current crisis that started during the 2007 has gone through two phases, which are reflected on the NMS, especially after September 2008 (Gardo and Martin, 2010). When the first phase of the crisis focused primarily on the interbank market volatility, the second phase spread on the instability of public finance. Although the overall stance of public finances of the new members is better than the old member countries, the differences within the new group are significant (from the performer Estonia to the laggard Hungary). In this second phase, of sovereign CDS spreads have become a major variable for observation, focused on risks and expectations about the fiscal situation of different countries.

Several interesting theoretical and practical issues appear. First one is, whether there is a link in the NMS between expectations about the condition of the public finances and the dynamics of money markets, including integration of their money markets with the euro area. This mean investigating the links between fiscal and liquidity risks as major components of systemic risk, or, which is another manifestation of the above - a correlation between the macro (public), and micro (bank) dimensions of the systemic risk. Second, how the above link, if exists and a priori it should exist, will be developed in time and in different phases of a crisis and how it evolves according to different countries monetary regimes. This concerns mostly two opposite extreme monetary regimes, namely, currency boards (and quasi-fixed exchange rate) - Bulgaria, Estonia, Latvia, Lithuania, Croatia, or inflation targeting - Poland, Czech Republic, Hungary and Romania. Thus, our study is comparative in nature and allows opposing various monetary and exchanging rate regimes ${ }^{2}$.

After exposing our theoretical motivations and objectives (part 1), and briefly presenting the related studies and empirical strategies (part 2), we discussed the results form the daily data panels models and we stress some limitations and possible developments of our study.

\section{Theoretical motivation: integration of money markets and fiscal risks}

In the current global and European crisis several phases emerged, two of them are of particular importance. The first one is money market crisis when confidence between banks

\footnotetext{
${ }^{2}$ For details see review articles of Ball (2010) and Frankel (2010), and for Eastern Europe see Gardo and Martin (2010).
} 
ultimately led to deep changes in the principles and techniques of central bank monetary policies (quantitative easing, non-standard measures, abandonment of the so called separation principle etc...). The second phase concerns the crisis of public finances and public debt, which appears later and was largely cumulative result of massive fiscal stimulus taken at the outset and designed to help the banking sector and to compensate for the ineffectiveness of monetary measures ${ }^{3}$.

In the first phase the attention of investors, bankers, and businesses interested in European economy was nailed on the state of money market, although a theoretical perspective, such markets have been in same respects forgotten and unexplored (Holthausen and Pill (2010) ${ }^{4}$. After a long period of convergence and stability these markets started to experience sharp fluctuations (mainly increases) and pronounced divergence of national interest rates dynamics ${ }^{5}$. Short-term interest rates (unsecured overnight interest rates, and 3 months rates) were of particular importance because they reflect not only changes in shortterm liquidity of the banking sector, but also confidence in the banking system as a whole. Shorts term interest rates are closely related to the formation of a term structure of the yield curve, indicator of current and anticipated economic development, and they represented a major signal for future interventions by central banks. On the charts 1 and 2 are presented the respectively the overnight interest rates dynamics and 3 month money market rate dynamics, compared to the ECB credit and deposit facilities interest rates.

Chart 1 Dynamics of overnight interest rates in New Member States
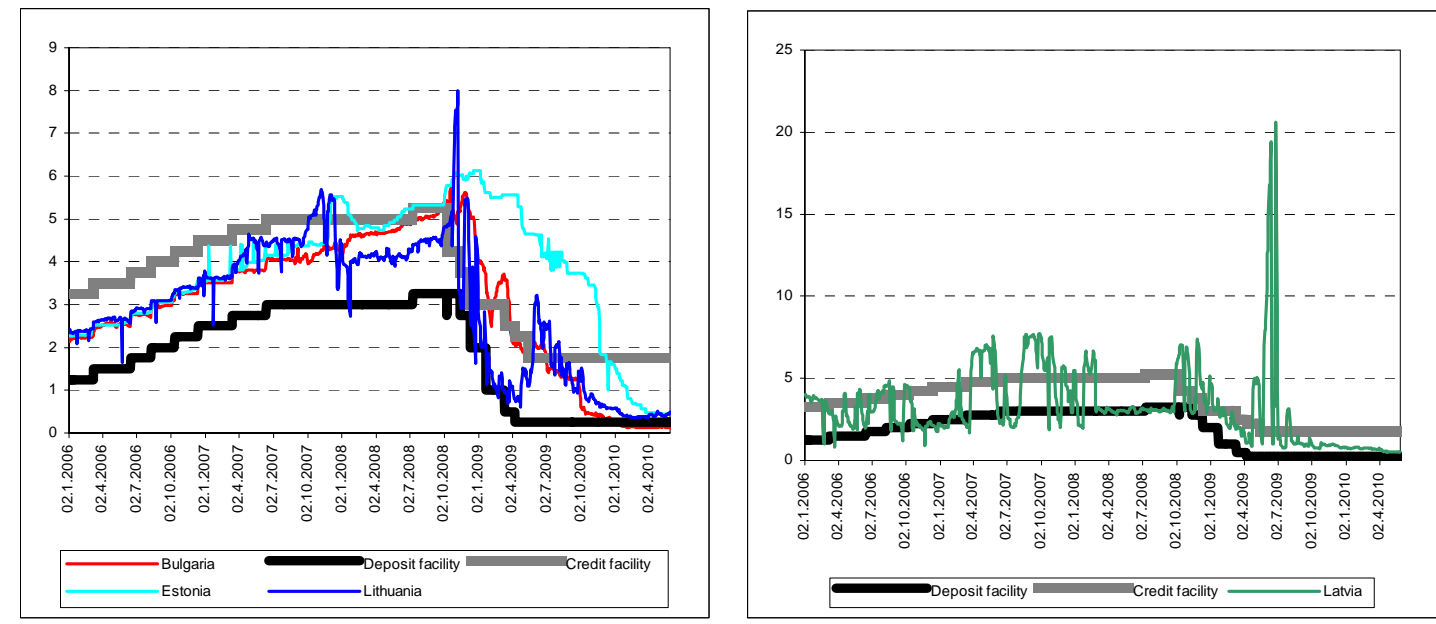

\footnotetext{
${ }^{3}$ See details for Ecofin (2009), BNB (2010), ECB, (2010), Berglof and al. (2009), Gardo and Martin (2010), Cerisier (2010), Bordes and Clerc (2010).

${ }^{4}$ According to Di Fiore and Tristani (2010, p. 10): "Some of the links between financial markets and the macroeconomy remain imperfectly understood, notably the link between interbank markets and aggregate economic dynamics".

${ }^{5}$ Key turning points were in August 2007 and September 2008, when they were coordinated and sharply reduced key interest rates of leading central banks to arrive in June 2009 when the ECB injected a huge amount of 442 billion euros.
} 

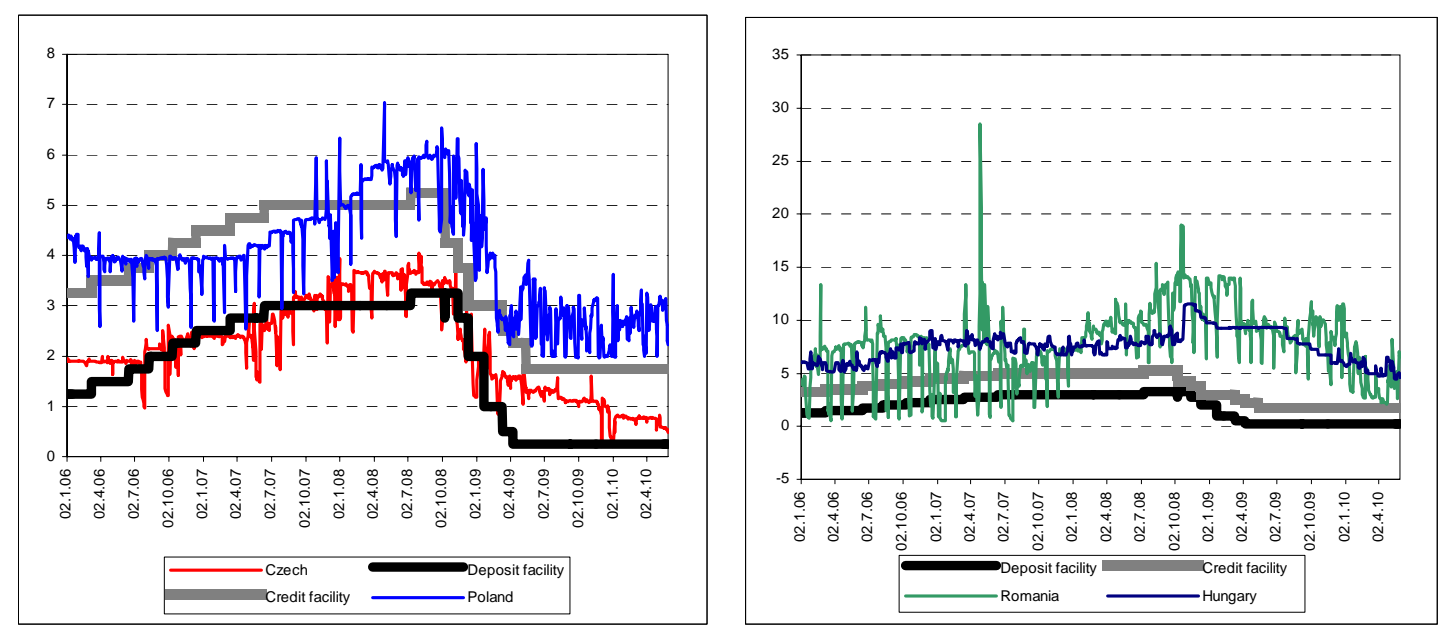

Chart 2 Dynamics of 3 months interest rates in new member states
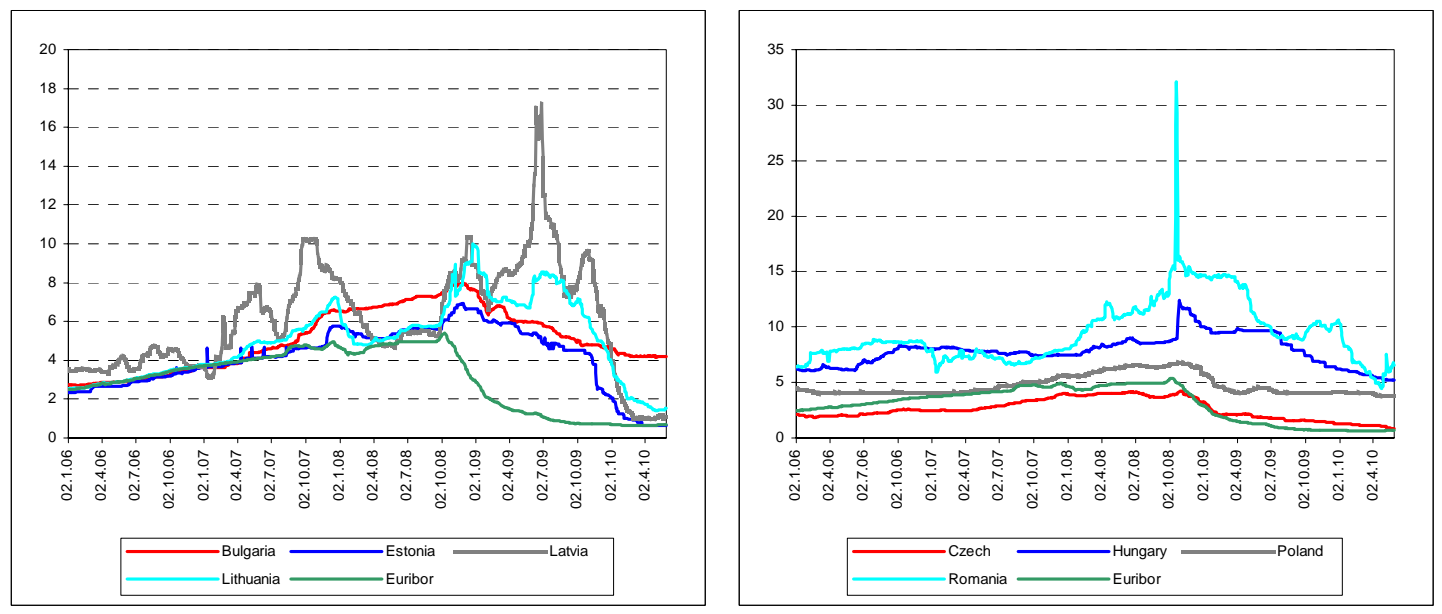

As to the second phase of the crisis, the attention of investors, bankers and politicians was focused on different indicators for fiscal risks (default, payment arrears on sovereign bonds, etc.), including spreads of $\mathrm{CDS}^{6}$ which highs reached in March 2009 and mid-April 2010 (see chart 3). When the interest spreads in the interbank market, showing the state of confidence in the banking system and micro-level risks, CDS is indicator for the confidence into the sustainability of fiscal and debt policy, i.e. macro-risks.

\footnotetext{
${ }^{6}$ The market for CDS (credit default swap) as part of the market in credit derivatives has grown particularly rapidly in the last decade, resulting in standardized and certain technical innovations which continue today, see for details (Packer and Suthiphongcahi, 2003; ICE , 2010).
} 
Chart 3 Dynamics of the CDS to the new member states
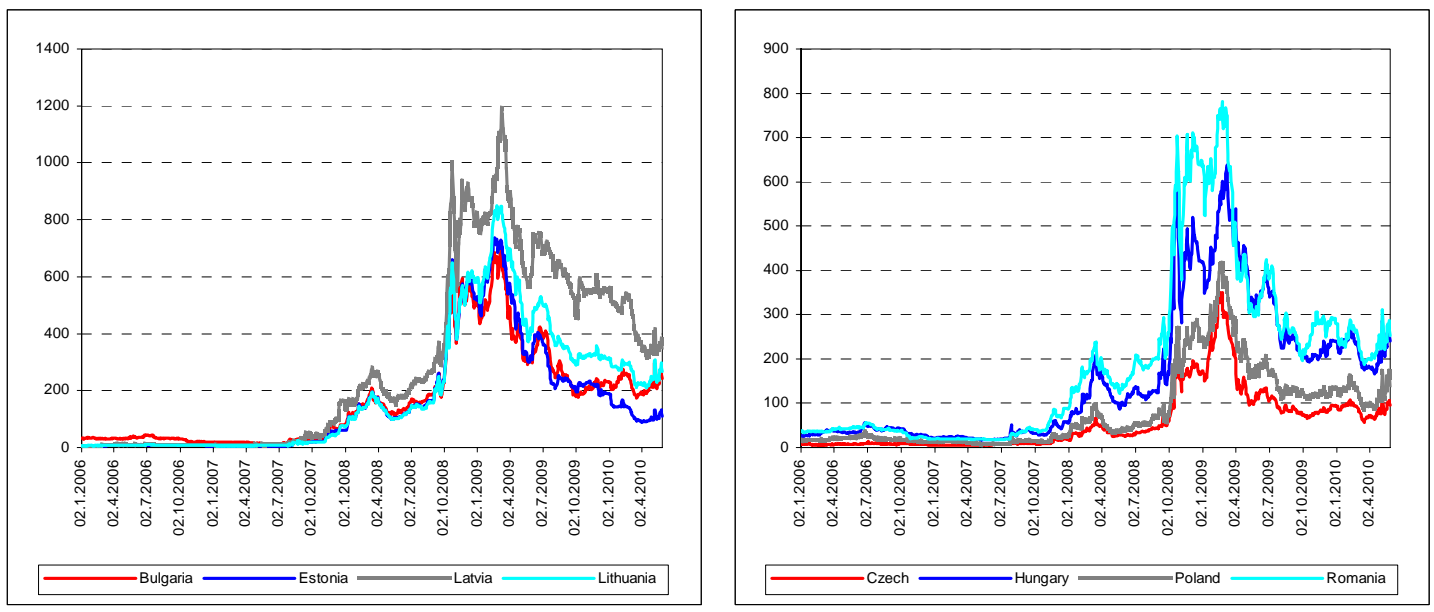

There is no doubt that different links exit between the state of confidence in the interbank market and confidence in public finances as integral parts of systemic risk and financial stability (chart 4).

Chart 4 Money market risk and public finance risk as a part of the systemic risk

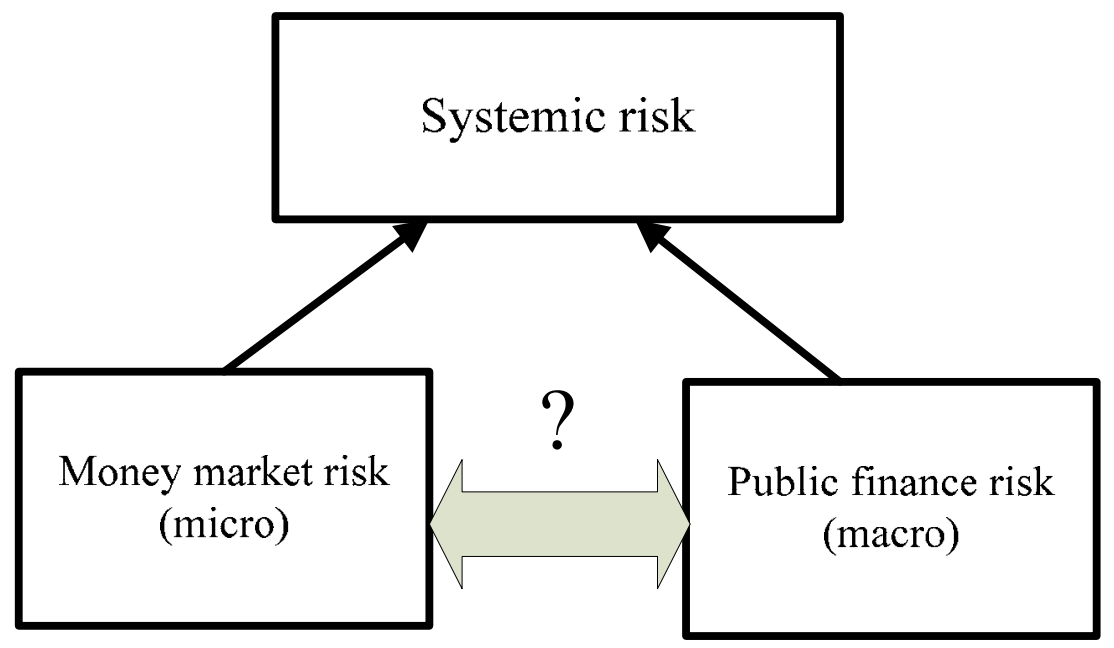

First, the impact of fiscal risks on the money market going through changes in bank balance sheets where sovereign securities are presented. Any worsening of expectations for a moratorium or debt restructurings automatically reflected on the state of the banking system, the CDS of individual banks is rising, and hence on the price of money market.

Second, opposite influence exists, from money market interest rates to fiscal imbalances, and is expressed primarily in the fact that the government is the guaranty of the stability of the banking sector, evidenced by a series of measures of bank capitalization and restructuring. Thus, any disturbance of the money market and more expensive resources, leads to accumulation of costs for the budget and ultimately worsen the solvency of governments. 
In the NMS, the links already mentioned are interwoven theoretical and practical problems associated with the dynamics of convergence and comparative effectiveness of different monetary regimes.

First, as mentioned in the introduction, before the crisis the main issue for the comparative analysis concerned the choice of monetary and currency exchange regimes for achieving monetary and real convergence. Monetary convergence, i.e. similar movement of interest rates with that in the euro area members was considered and is considered the minimum requirement for a successful adoption of the common monetary policy. In this sense, the interest rate channel and inter-bank interest rates are leading link in the chain of transmission mechanism. Crisis change things or at least put them in new conditions. It not only cast doubt on the sustainability of the trend towards monetary integration in the NMS, but also gave impetus to the destruction of the monolithic behavior of the new countries, allowing identifying different individual trajectories, depending on the state of public finance, banking systems, and overall structural reforms. Roughly crisis gave a new opportunity for expression of the diversity of transition, which has long been subject to thorough analysis and numerous publications ${ }^{7}$.

Second, the dynamics of monetary convergence especially that of the interbank market, considered within the broader discussion on optimality of the European currency zone, and allows the benchmarking of monetary regimes performance in the NMS. This concern the current state of the almost bipolar choice of monetary regimes, on the one side Currency boards and quasi-fixed rates in Estonia, Latvia, Lithuania, Bulgaria and on the other side inflation targeting and floating rates in the Republic, Hungary, Poland and Romania ${ }^{8}$. The bipolar situation provides opportunities for almost a natural experiment for the success of the two different monetary systems ${ }^{9}$. In fact this polarity was reached through a long evolution, in which stood out different trends and groupings (Nenovsky, 2009).

Third, disputes between supporters of the CBA and inflation targeting in postcommunist countries have a long history, which acquires real practical terms. It is generally believed that Currency boards give greater opportunities for rapid monetary integration, because the interest rates passively follow the euro area, due to the effects of credibility and discipline ${ }^{10}$. Credibility and discipline effects provide an opportunity for a tight fiscal policy and low public debt ${ }^{11}$. For its part, proponents of inflation targeting indicate that this arrangement allows for greater autonomy and monetary response to asymmetric shocks, and that the Currency boards are highly vulnerable. According to them, the effects of credibility and discipline are not weaker under the regime of monetary discretion than under the rigid monetary rule. Experience shows, however, that the state of the MNS and certain preconditions for the integration of the euro area, the opportunities for independent monetary policy are small and almost insignificant. This is confirmed by the behavior of interest rates before the start of the crisis, which had similar convergence dynamics.

\footnotetext{
${ }^{7}$ See Kornai (2000), Aslund (2002), Colombatto (2002), Winiecki (2004), Csaba (2007), Bohle and Greskovits (2007), Havrylyshin (2009) and others.

${ }^{8}$ Slovakia and Slovenia are not subject to analysis; they are full members of the eurozone.

${ }^{9}$ See e.g. the discussion about the comparative success of different countries in combating the crisis made in Aslund (2009) and Gardo and Martin (2010). Aslund said the main reason for the crisis is the course currency regime and the crisis is particularly serious where the scheme is rigid (Currency boards) and relatively mild pass to inflation targeting. Although Aslund's theoretical considerations are interesting, the facts, however, do not confirm his claim, even opposite. Telling evidence is the comparative situation of Estonia and Hungary, considered the first member of the eurozone by 2011, and the second - the boundaries of financial collapse.

${ }^{10}$ See for the functioning of currency boards Gulde () Nenovsky and Hristov (2002), Nenovsky, Hristov and Mihaylov (2002). For the inflation targeting experience in Eastern Europe see ().

${ }^{11}$ Although in general practice confirms these relationships, in reality situation with currency boards are more complex and the trajectories of the two effects (credibility and discipline) are complex and nonlinear dynamics (Raybaut and Torre, 2005).
} 


\section{Related studies and empirical models}

For the purposes of empirical measurement general theoretical relationship between bank and fiscal risks is limited to an analysis of the relationship between short-term interest rates on money market (overnight interest rates and three-month interest rates) and spreads on sovereign CDS premiums in different phases of the crisis, as well as two main monetary regime. Countries are examined in two groups of countries, four fixed-rate and four with inflation targeting. The first group included, the Baltic countries at the beginning of 90 years chose a fixed exchange rate regimes (Estonia, 1992, Latvia 1993, Lithuania, 1994) associated with geo-strategic choice for separation from the Soviet zone and monetary integration in Europe system. They add Bulgaria, which in 1997 introduced a currency board. The second group of countries is that inflation targeting selected. Here are the countries of Central Europe (Czech Republic, 1998, Poland, 2000, Hungary, 2001) and Romania (2005).

Several studies may be useful for our analysis, although most of them did not deal with or directly tested our dependencies. The dynamics of the whole multitude of interest rates in new member states has been studied thoroughly and in detail by Egert and al. (2007) in connection with problems of interest rate pass through in 5 countries of Central Europe, and Cuaresma and Wojcik (2006) to measure the monetary independence of Hungary, Poland and Czechoslovakia, in different periods of exchange rate regimes (1993- 2003). Using DCCMGARCH modeling of the second study the authors found confirmation of the hypothesis of greater independence at a floating rate and more in fixed. At the same bed and same parties is the study of Habib (2002), which concentrate on short-term interest rates, and finds a lack of dependence of interest rates in Germany.

As for NMS sovereign CDS spreads lack independent studies of their dynamics. Indeed, the attention of researchers on the behavior of the CDS spreads is recent, and directions for future research are numerous. Several authors establish empirically that these spreads reflect quite well the state of fiscal risks and in a sense give more and better information than sovereign ratings (Shino and Takahashi, 2010). These authors suggest that the relationship between CDS spreads and public debt was especially shown for the countries of Southern Europe (Greece, Portugal, Spain, and Italy). For its part Ismailescu and Kazemi (2010) examined the response of the CDS spreads in emerging markets in terms of changes in ratings during 2001-2008 and found that positive changes in ratings have a stronger effect on CDS that negative changes. An interesting empirical analysis of shocks on the return on bank assets of major U.S. and European banks caused by the bank CDS indices is represented in Calice and Ioannidis (2009).

As for modeling of overnight interest rates, it has a long tradition (Hamilton, 1996; Hamilton and Jorda, 2002) and is subject to numerous and interesting attempts to account a number of institutional and organizational factors in the EU money market (Nautz and Offermanns, 2006; Bartolini and Prati, 2006; Cassola and Mmorana, 2008; Linzert and Schmidt, 2008), and the effects of the crisis Holthausen and Pill (2010). Modeling of overnight interest rates under a Currency board, in the case of Bulgaria was made by Nenovsky and Chobanov (2004).

The main novelty of the present study is to investigate the direct link between monetary and liquidity risk from one side and fiscal and country risk from others side. Our empirical strategy is to run the panel models, linking overnight interest rate and sovereign CDS spreads of new member states (taken either as level, or deviation from European level). The original database we use includes daily observations for short-term interest rates and sovereign CDS rates for the period January, 2006, to June 2010, eighth countries (Estonia, Latvia, Lithuania, Bulgaria, Poland, Hungary, Czech Republic and Romania) for Eonia (Euro Overnight Index Average) and 3-month Euribor (Euro Interbank Offered Rate), and sovereign CDS for 
Germany. We run the panel firstly for the entire period, and later we split the period into two parts, prior to the crisis, and during the crisis.

The first group of model (equation 1 and 2 below) present the equations of the panel model, where NMS interest rates taken as deviation from to EU benchmark:

(1) $d\left(i o_{i t}-i o_{t}^{*}\right)=\alpha_{i t}+\alpha_{1 i} d\left(i_{i t}-i_{t}^{*}\right)+\alpha_{2 i} d\left(i 3_{i t}-i 3_{t}^{*}\right)+\alpha_{3 i} d\left(s_{i t}-s_{t}^{*}\right)+\varepsilon_{i t}$

(2) $d\left(i o_{i t}-i o_{t}^{*}\right)=\alpha_{i t}+\alpha_{2 i} d\left(i 3_{i t}-i 3_{t}^{*}\right)+\alpha_{3 i} d\left(s_{i t}-s_{t}^{*}\right)+\varepsilon_{i t}$

In (1) and (2) io denotes overnight interest rates in the new members sates and $i o^{*}$ denotes Eonia, $i 3$ presents short 3 months rates, $i 3^{*}$ presents 3-month Euribor, $i$ and $i *$ presents the policy rates and finally $s$ and $s^{*}$ denote respectively sovereign CDS spreads to new countries and those of Germany. The subscript $i$ is for country effect, and $t-$ for the time effect. The model (1) was used for countries with inflation targeting regime where the policy rate is discretionary formulated. In the case of Currency boards countries (and fixers, like Latvia), there is not discretionary policy rate, and where this rate is announced it is of purely administrative, statistical and judiciary objectives, therefore the equation (1) becomes (2).

The second group deals with the same relation between fiscal and liquidity risk, and the variables are taken independently (not as a spread) and the EU short term rates appear as explanatory variables. In this case we run the following two panels, (3) for inflation targeters and (4) for currency boards countries:

(3) $d\left(i o_{i t}\right)=\alpha_{i t}+\alpha_{1 i} d\left(i_{i t}\right)+\alpha_{2 i} d\left(i 3_{i t}\right)+\alpha_{3 i} d\left(s_{i t}\right)+\alpha_{4} d\left(i o^{*}\right)+\alpha_{5} d\left(i 3^{*}\right)+\varepsilon_{i t}$

(4) $d\left(i o_{i t}\right)=\alpha_{i t}+\alpha_{2 i} d\left(i 3_{i t}\right)+\alpha_{3 i} d\left(s_{i t}\right)+\alpha_{4} d\left(i o^{*}\right)+\alpha_{5} d\left(i 3^{*}\right)+\varepsilon_{i t}$

The results obtained are presented in the tables 1 and 2 . 
Table 1 Models in spreads (equations 1 and 2)

\begin{tabular}{|c|c|c|c|}
\hline & $\begin{array}{l}\text { Entire period } \\
\text { 06/2006:05/2010 }\end{array}$ & $\begin{array}{l}\text { Prior to the crisis } \\
\text { 06/2006:09/2008 }\end{array}$ & $\begin{array}{l}\text { Crisis period } \\
\text { 10/2008:05/2010 }\end{array}$ \\
\hline $\begin{array}{l}\text { Fixed exchange rate } \\
\text { (Bulgaria, Estonia, } \\
\text { Lithuania, Latvia) }\end{array}$ & $\begin{array}{l}\alpha=-0.0017(-0.25) \\
\alpha 2=1.563(26.84)^{*} \\
\alpha 3=0.0016(2.72)^{*} \\
R 2=0.1396 \\
D W=1.7792 \\
\text { Obs } 4580\end{array}$ & $\begin{array}{l}\alpha=-0.0001(-0.024) \\
\alpha 2=0.6930(9.46)^{*} \\
\alpha 3=0.00007(0.05) \\
R 2=0.0306 \\
\text { DW }=1.8792 \\
\text { Obs } 2844\end{array}$ & $\begin{array}{l}\alpha=-0.002(-0.16) \\
\alpha 2=1.8583(19.79)^{*} \\
\alpha 3=0.0014(1.76)^{* * *} \\
\text { R2 }=0.1890 \\
\text { DW }=1.7324 \\
\text { Obs } 1736\end{array}$ \\
\hline $\begin{array}{l}\text { Inflation targeting } \\
\text { (Poland, Hungary, } \\
\text { Czech Republic, } \\
\text { Romania) }\end{array}$ & $\begin{array}{l}\alpha=0.0007(0.06) \\
\alpha 1=0.5512(3.89)^{*} \\
\alpha 2=0.5517(10.19)^{*} \\
\alpha 3=-0.0007(-0.51) \\
R 2=0.0266 \\
D W=2.0998 \\
\text { Obs } 4580\end{array}$ & $\begin{array}{l}\alpha=0.0012(0.08) \\
\alpha 1=1.0428(3.57)^{*} \\
\alpha 2=2.6563(10.85)^{*} \\
\alpha 3=-0.0149(-3.17)^{*} \\
R 2=0.0482 \\
D W=2.06 \\
\text { Obs } 2844\end{array}$ & $\begin{array}{l}\alpha=0.0005(0.0329) \\
\alpha 1=0.3377(2.39)^{* *} \\
\alpha 2=0.4349(9.11)^{*} \\
\alpha 3=0.0007(0.59) \\
R 2=0.0507 \\
D W=2.26 \\
\text { Obs } 1736\end{array}$ \\
\hline $\begin{array}{l}\text { Deficits countries } \\
\text { (Hungary, Latvia } \\
\text { Romania) }\end{array}$ & $\begin{array}{l}\alpha=0.0003(0.02) \\
\alpha 1=0.2653(1.39) \\
\alpha 2=0.7807(12.21)^{*} \\
\alpha 3=0.0012(0.90) \\
R 2=0.0430 \\
\text { DW }=1.9854 \\
\text { Obs } 3435\end{array}$ & $\begin{array}{l}\alpha=0.0015(0.07) \\
\alpha 1=0.9919(2.75)^{*} \\
\alpha 2=1.8876(8.47)^{*} \\
\alpha 3=-0.0111(-2.25)^{* *} \\
R 2=0.0389 \\
D W=2.0225 \\
\text { Obs } 2133\end{array}$ & $\begin{array}{l}\alpha=0.0004(0.01) \\
\alpha 1=-0.0186(-0.08) \\
\alpha 2=0.69(10.10)^{*} \\
\alpha 3=0.0022(1.57) \\
R 2=0.0747 \\
D W=1.9593 \\
\text { Obs } 1302\end{array}$ \\
\hline
\end{tabular}

* - significant at $1 \% ; * *$-significant at 5\%; *** - significant at $10 \%$ 
Table 2 Models in levels (equations 3 and 4)

\begin{tabular}{|c|c|c|c|}
\hline & $\begin{array}{l}\text { Entire period } \\
\text { 06/2006:05/2010 }\end{array}$ & $\begin{array}{l}\text { Prior to the crisis } \\
\text { 06/2006:09/2008 }\end{array}$ & $\begin{array}{l}\text { Crisis period } \\
\text { 10/2008:05/2010 }\end{array}$ \\
\hline $\begin{array}{l}\text { Fixed exchange rate } \\
\text { (Bulgaria, Estonia, } \\
\text { Lithuania) }\end{array}$ & $\begin{array}{l}\alpha=-0.0005(-0.19) \\
\alpha 2=0.8119(25.29)^{*} \\
\alpha 3=0.0007(3.26)^{*} \\
\alpha 4=0.0462(2.04)^{* *} \\
\alpha 5=0.6247(4.54)^{*} \\
R 2=0.1720 \\
\text { DW }=2.0185 \\
\text { Obs } 3435\end{array}$ & $\begin{array}{l}\alpha=0.0001(-0.06) \\
\alpha 2=0.5294(15.23)^{*} \\
\alpha 3=-0.0004(-0.71) \\
\alpha 4=0.0795(3.72)^{*} \\
\alpha 5=0.2466(1.66)^{* * *} \\
R 2=0.1063 \\
\text { DW }=2.2964 \\
\text { Obs } 2133\end{array}$ & $\begin{array}{l}\alpha=0.0102(1.73)^{* * *} \\
\alpha 2=0.9847(17.67)^{*} \\
\alpha 3=0.0007(2.35)^{* *} \\
\alpha 4=0.0069(0.16) \\
\alpha 5=1.1345(4.13)^{*}\end{array}$ \\
\hline $\begin{array}{l}\text { Inflation targeting } \\
\text { (Poland, Hungary, } \\
\text { Czech Republic, } \\
\text { Romania) }\end{array}$ & $\begin{array}{l}\alpha=0.006(0.05) \\
\alpha 1=0.4199(2.55)^{* *} \\
\alpha 2=0.5540(10.26)^{*} \\
\alpha 3=-0.0008(-0.67) \\
\alpha 4=0.0814(0.72) \\
\alpha 5=0.09(0.13) \\
R 2=0.0251 \\
D W=2.0992 \\
\text { Obs } 4580\end{array}$ & $\begin{array}{l}\alpha=-0.0059(-0.36) \\
\alpha 1=0.8274(2.48)^{* *} \\
\alpha 2=2.7048(10.95)^{*} \\
\alpha 3=-0.0150(-3.12)^{*} \\
\alpha 4=0.0152(0.09) \\
\alpha 5=-0.7713(-0.64) \\
R 2=0.0463 \\
\text { DW }=2.0609 \\
\text { Obs } 2844\end{array}$ & $\begin{array}{l}\alpha=0.0040(0.21) \\
\alpha 1=0.2277(1.37) \\
\alpha 2=0.4380(9.21)^{*} \\
\alpha 3=0.0003(0.30) \\
\alpha 4=0.1841(1.36) \\
\alpha 5=0.4040(0.47) \\
\text { R2=0.0502 } \\
D W=2.2632 \\
\text { Obs } 1736\end{array}$ \\
\hline $\begin{array}{l}\text { Deficits countries } \\
\text { (Hungary, Latvia } \\
\text { Romania) }\end{array}$ & $\begin{array}{l}\alpha=0.0011(0.06) \\
\alpha 1=0.0932(0.43) \\
\alpha 2=0.7859(12.37)^{*} \\
\alpha 3=0.0009(0.65) \\
\alpha 4=-0.3857(-2.28)^{* *} \\
\alpha 5=1.1740(1.14) \\
\text { R2 }=0.0449 \\
\text { DW }=1.9819 \\
\text { Obs 3435 }\end{array}$ & $\begin{array}{l}\alpha=-0.0062(-0.27) \\
\alpha 1=0.7669(1.92)^{* * *} \\
\alpha 2=1.9204(8.61)^{*} \\
\alpha 3=-0.0109(-2.17)^{* *} \\
\alpha 4=-0.1148(0.48) \\
\alpha 5=0.2834(0.17) \\
\text { R2=0.0382 } \\
\text { DW }=2.0221 \\
\text { Obs } 2133\end{array}$ & $\begin{array}{l}\alpha=0.0120(0.37) \\
\alpha 1=-0.1792(-0.70) \\
\alpha 2=0.6943(10.30)^{*} \\
\alpha 3=0.0016(1.19) \\
\alpha 4=-0.6320(-2.64)^{*} \\
\alpha 5=1.9381(1.27) \\
R 2=0.0817 \\
D W=1.9532 \\
\text { Obs } 1302\end{array}$ \\
\hline
\end{tabular}

* - significant at $1 \%$; ${ }^{* *}$-significant at $5 \%$; *** - significant at $10 \%$

Discussion of the results and concluding remarks 
According to the results we can observe that inflation targeting and pegged exchange rate NMS demonstrate significant differences in terms of monetary integration and the perception of fiscal risk. Overnight interest rate spread under fixed exchange rate in normal times depends on monetary factors mainly on expectations about future behavior of interest rates and an assessment of the liquidity situation presented by the three-month spread. In the same period for inflation targeting countries some role plays the spread in policy rates and CDS. The relationship between policy rate and overnight has the expected positive sign. The relationship with CDS is negative, which at first glance does not confirm the theoretical assumption of the link between the monetary and fiscal risk. In fact the pre-crisis period is characterized by a cycle of rising interest rates by the ECB, accompanied by plenty of liquidity for countries with inflation targeting. And when the tries to tighten monetary policy were observed, this is not the case in respect of the fiscal efforts. There were budget deficits regardless of the upward phase of the cycle. Pro-cyclical fiscal policy is not always reflected by an adequate change of the CDS spread due to high economic growth and the underestimation of the inherent risks. Therefore, both risks - monetary and fiscal move together.

Some of the NMS are characterized by high volatility in its monetary variables, high budget deficits, and vulnerability to shocks that force them to seek assistance from IMF and EU. Due to similarities in their behavior we separated them into the third group called "deficit countries". Before the crisis the behavior of spreads is similar to that of inflation targeting countries. Although with fixed exchange rate we decided to put Latvia here because of macroeconomic similarities with the deficit and low disciplined countries.

The crisis has changed the relationship between liquidity and fiscal risks. Fiscal risks approximated by the CDS spreads are statistically significant in the group of fixed NMS, which mean that higher fiscal risk leads to further rise of the liquidity risks, i.e. short term interest rates. However, for inflation targeting countries CDS spreads are insignificant, as is could be observed also on the chart 3 , when he remains at the lower levels than for fixed NMS. This is another illustration of the fact that the fixed exchange rates are perceived as riskier when using macro policy for coping with the external shocks. But such risk assessment finds no real confirmation in practice, since the countries with currency board are not turned to international institutions during the crisis, and moreover, Estonia was admitted to the eurozone (January, 2011) by satisfying the necessary Maastricht criteria.

In terms of equations for overnight interest rates the expected relationships were confirmed. The hypotheses of greater degree of monetary integration with the euro before the crisis for the NMS with fixed exchange rate, and the importance of the proper monetary policy for countries with inflation targeting regime were supported. Deficits countries have the same behavior as inflation targeting. The crisis leads to disconnect between overnight interest rates in NMS and euro area, however the impact of euro area monetary variables is observed mainly through the expectations of future interest rate behavior, represented by the three months interest rates. The importance of external perception of fiscal risks increases and CDS were statistically significant with the expected sign. The crisis leads to a strong reduction of the impact of its own monetary policy on overnight interest rates for inflation targeting and deficits countries and became statistically insignificant. Concerning deficits countries the overnight interest rates moves in the opposite direction from that of the Eonia.

In conclusion we can say that the results obtained form the high frequency panel data models support the theoretical hypotheses and policy intuition that exists strong relationship between the liquidity risk (measured by the short term money markets) and fiscal risk (measured by CDS) and that this link is extremely unstable during the financial crisis. The relative performance of different monetary regimes concerning the liquidity-fiscal risk 
connection is debatable, and although the countries with currency boards is perceived as more vulnerable, the recent practice shows that they are more stable, and did not resorts to foreign financial assistance, at least for now.

\section{Bibliography}

Aslund, A.(2002) "Building capitalism. The transformation of the former soviet bloc" Cambridge : Cambridge University Press, 2002

Åslund, A.(2009) "The East European Financial Crisis”. Case Network Studies\&Analysis, No 359/2009.

Ball, S. (2010). "The performance of alternative monetary regimes", NBER WP N 16124

Barisitz, St. "Banking Transformation (1989-2006) in Central and Eastern Europe - with Special Reference to Balkans”. Bank of Greece, Working Paper, 78 (2008)

Bartolini, L, Al. Prati. "Cross-country differences in monetary policy execution and money market rates' volatility". European Economic Review 50 (2006): 349-376.

Bohle, D., B. Greskovits. "The State, Internationalization, and Capitalist Diversity in Eastern Europe, Competition and Change ”, 11, 2, (2007): 89-115.

Calice, G., Ch. Ioannidis. "An Emperical Analysis of the Impact of the Credit Default Swap Index Market on Large Complex Financial Institutions”, 2009, http//ssrn.com/abstract=1447403

Cassola, N., C. Morana. (2008). "Modeling Short-Term Interest Rate Spreads in the Euro Money Market”. International Journal of Central banking, vol.4, No 4, December 2008.

Cerisier, F. (2010). "France: decisions time on public finances”, BNB conjuncture, July August, pp. 3-13.

Chobanov, P., N. Nenovsky. (2004) "Money market liquidity under Currency board - empirical investigations for Bulgaria”, William Davidson Institute Working Paper, N 693, May 2004.

Colombatto, E. "Is there and Austrian Approach to Transition?" The Review of Austrian Economics, 1, 15 (2002): 61- 74.

Csaba, L. "The New Political Economy of Emerging Europe".Budapest: Akadémiai Kiadó/Kluwer, 2007.

Cuaresma, J. Cr., C. Wójcik. (2006) "Measuring monetary independence: Evidence from a group of new EU member countries", Journal of Comparative Economics 34 (2006): 24-43.

De Fiore, F., O. Tristani. "Financial conditions and monetary policy", ECB Research Bulletin, No 9, (2010): 10-12.

ECB (2010). "The ECB's Monetary Policy Stance During the Financial Crisis", Montly Bulletin, January 2010.

ECOFIN (2009). "Economic Crisis in Europe: Causes, Consequences and Responses, European Economy ", N 7

Égert, B., J. C, Cuaresma and Th. Reinger. "Interest rate pass- through in central and eastern Europe: Reborn from ashes merely to pass away", Journal of Policy Modeling 29,(2007):209-225.

Frankel, J. (2010). "Monetary policy in emerging markets : a survey", NBER, WP 16125

Gardo, S., R. Martin (2010). "The impact of the global economic and financial crisis on central, eastern and south-eastern Europe, a stock-taking exercise", ECB Occasional Paper N 114.

Hamilton, J. D. (1996), "The Daily Market for Federal Funds", The Journal of Political Economy, vol.104, No1, (1996): 26-56.

Hamilton, J. D, Ò. Jordà. (2000), "A model of the Federal Funds Rate Target". The Journal of Political Economy, vol.110, No5, (2000): 1135-1167.

ICE, " Global Credit Derivates Markets Overview: Evolution, stendartization and Cleaning", March 2010.

Ismailescu, I., H. Kazemi. "The reaction of emerging market credit default swap spreads to sovereign credit rating changes", Journal of Banking\&Finance, forthcoming.

Kornai, J. "What the Change of System From Socialism to Capitalism Does and Does Not Mean". Journal of Economic Perspectives 14, 1 (2000): 27-42. 
Linzert, T., S. Schmidt. "What Explains the Spread Between the Euro Overnight Rate and the ECB's Policy Rate”,ECB Working Paper Series, No983/ December 2008.

Nautz, D., Ch. Offermanns. "The dynamic relationship between the Euro overnight rate, the ECB's policy rate and the term spread", Deutsche Bundesbank, Disscussion Paper, Series 1: Economic Studies, No 01/2006.

Nenovsky, N. "Monetary Regimes in Post-Communist Countries: Some Long-Term Reflections". Sofia: Agency for Economic Analysis and Forecasting WP 2 (2009).

Packer, F., Ch. Suthiphongchai. "Sovereign credit default swaps", BIS Quaterly Review, December 2003.

Raybaut, A., D. Torre (2005). Discipline, confiance et stabilité des régimes de caisses d'émission en transition vers l'euro, Colloque international, Marrakech, March 2005

Shino J., Ko. Takahashi. "Sovereign Credit Default Swaps: Market Developments and Factors behind Price Changes", Bank of Japan Review, April 2010.

Winiecki, Jan. "Determinants of Catching Up or Falling Behind: Interaction of Formal and Informal Institutions". Post-Communist Economies 162 (2004): 137-152. 


\section{DAVIDSON INSTITUTE WORKING PAPER SERIES - Most Recent Papers}

The entire Working Paper Series may be downloaded free of charge at: www.wdi.umich.edu

CURRENT AS OF $11 / 4 / 10$

\begin{tabular}{|c|c|c|}
\hline Publication & Authors & Date \\
\hline $\begin{array}{l}\text { No. 1002: Money Market Integration and Sovereign CDS Spreads } \\
\text { Dynamics in the New EU States }\end{array}$ & $\begin{array}{l}\text { Peter Chobanov, Amine Lahiani } \\
\text { and Nikolay Nenovsky }\end{array}$ & Oct 2010 \\
\hline No. 1001: Modeling transition in Central Asia: the Case of Kazakhstan & $\begin{array}{l}\text { Gilles DUFRENOT, Adelya } \\
\text { OSPANOVA, Alain SAND- } \\
\text { Zantman }\end{array}$ & Oct 2010 \\
\hline $\begin{array}{l}\text { No.1000: Unlocking Productive Entrepreneurship in Ethiopia: } \\
\text { Which Incentives Matter? }\end{array}$ & Zuzana Brixiova & Oct 2010 \\
\hline No.999: Price convergence and market integration in Russia & Konstantin Gluschenko & Sept 2010 \\
\hline $\begin{array}{l}\text { No. 998: Bank Efficiency in Transitional Countries: Sensitivity to } \\
\text { Stochastic Frontier Design }\end{array}$ & Zuzana Irsova & Sept 2010 \\
\hline $\begin{array}{l}\text { No. 997: EU Enlargement and Monetary Regimes from the Insurance } \\
\text { Model Perspectives }\end{array}$ & Nikolay Nenovsky & June 2010 \\
\hline $\begin{array}{l}\text { No. 996: Which Foreigners are Worth Wooing? } \\
\text { A Meta-Analysis of Vertical Spillovers from FDI }\end{array}$ & $\begin{array}{c}\text { Tomas Havranek and } \\
\text { Zuzana Irsova }\end{array}$ & June 2010 \\
\hline $\begin{array}{l}\text { No. 995: Environmental Regulation and Competitiveness: } \\
\text { Evidence from Romania }\end{array}$ & $\begin{array}{c}\text { Guglielmo M. Caporale, } \\
\text { Christophe Rault, Robert Sova \& } \\
\text { Anamaria Sova }\end{array}$ & June 2010 \\
\hline $\begin{array}{l}\text { No. 994: Pollution Abatement And Control Expenditure In Romania: } \\
\text { A Multilevel Analysis }\end{array}$ & $\begin{array}{c}\text { Guglielmo M. Caporale, } \\
\text { Christophe Rault, Robert Sova \& } \\
\text { Anamaria Sova } \\
\end{array}$ & June 2010 \\
\hline $\begin{array}{l}\text { No. 993: Do Innovative Workplace Practices Foster Mutual Gains? } \\
\text { Evidence From Croatia }\end{array}$ & Derek Jones and Srecko Goic & May 2010 \\
\hline $\begin{array}{l}\text { No. 992: Firm And Employee Effects Of An Enterprise Information } \\
\text { System: Micro-Econometric Evidence }\end{array}$ & $\begin{array}{l}\text { Derek Jones, Panu Kalmi } \\
\text { and Antti Kauhanen }\end{array}$ & June 2010 \\
\hline $\begin{array}{l}\text { No. 991: Catching-up and inflation in Europe: Balassa- } \\
\text { Samuelson, Engel's Law and other Culprits }\end{array}$ & Balázs Égert & June 2010 \\
\hline $\begin{array}{l}\text { No. 990: UNLOCKING PRODUCTIVE ENTREPRENEURSHIP IN AFRICA'S LEAST } \\
\text { DEVELOPED COUNTRIES }\end{array}$ & Zuzana Brixiova & June 2010 \\
\hline $\begin{array}{l}\text { No. 989: The VARying Effect of Foreign Shocks in Central \& Eastern } \\
\text { Europe }\end{array}$ & $\begin{array}{l}\text { Rebeca Jimenez-Rodriguez, } \\
\text { Amalia Morales-Zumaquero } \\
\text { \& Balazs Egert }\end{array}$ & May 2010 \\
\hline $\begin{array}{l}\text { No. 988: Implications of Bank Ownership for the Credit Channel of } \\
\text { Monetary Policy Transmission: Evidence from India }\end{array}$ & $\begin{array}{l}\text { Sumon K. Bhaumik, Vinh Dang } \\
\text { and Ali M. Kutan }\end{array}$ & May 2010 \\
\hline $\begin{array}{l}\text { No. 987: Mother or motherland: Can a government have an impact on } \\
\text { educational attainment of the population? Preliminary evidence from } \\
\text { India }\end{array}$ & $\begin{array}{l}\text { Sumon Kumar Bhaumik and } \\
\text { Manisha Chakrabarty }\end{array}$ & May 2010 \\
\hline $\begin{array}{l}\text { No. 986: Does FDI spur innovation, productivity and knowledge sourcing } \\
\text { by incumbent firms? Evidence from manufacturing industry in Estonia }\end{array}$ & Priit Vahter & April 2010 \\
\hline No. 985: Exports and Property Prices in France: Are They Connected? & $\begin{array}{c}\text { Balazs Egert and } \\
\text { Rafal Kierzenkowski }\end{array}$ & May 2010 \\
\hline $\begin{array}{l}\text { No. 984: Methodologies of Analyzing Inter-Regional Income Inequality } \\
\text { and Their Applications to Russia }\end{array}$ & Konstantin Gluschenko & April 2010 \\
\hline $\begin{array}{l}\text { No. 983: Foreign News and Spillovers in Emerging European Stock } \\
\text { Markets }\end{array}$ & Evzen Kocenda and Jan Hanousek & $\begin{array}{l}\text { May } \\
2010\end{array}$ \\
\hline $\begin{array}{l}\text { No. 982: The Economic and Monetary Union's effect on (international) } \\
\text { trade: the case of Slovenia before euro adoption }\end{array}$ & $\begin{array}{l}\text { Aleksander Aristovnik and } \\
\text { Matevz Meze }\end{array}$ & $\begin{array}{l}\text { April } \\
2010\end{array}$ \\
\hline $\begin{array}{l}\text { No. 981: In Time of Troubles: Challenges and Prospects in the Middle } \\
\text { East and North Africa }\end{array}$ & Imed Drine & $\begin{array}{l}\text { April } \\
2010\end{array}$ \\
\hline
\end{tabular}

